\title{
Effect of long-term organic and mineral fertilisation on selected physico-chemical soil properties in rye monoculture and five-year crop rotation
}

\begin{abstract}
The research was carried out continuously since 1923 in a permanent fertilisation experiment at the Experimental Station of SGGW in Skierniewice. The objective of the research was to determine the effect of long-term fertilisation (Ca, CaNPK, NPK) and crop rotation systems (rye monoculture without fertilisation with manure and five-field rotation with legume crop and manure fertilisation) on selected physical and chemical soil properties. Long-term fertilisation caused various degrees of change in many physio-chemical properties in three soil horizons $\left(\mathrm{A}_{\mathrm{p}}, \mathrm{E}_{\mathrm{et}}, \mathrm{B}_{\mathrm{t}}\right)$ : $\mathrm{pH}$ in $\mathrm{KCl}$, cation exchange capacity, total exchangeable bases, base saturation, content of carbon, nitrogen and mineral forms of nitrogen $\left(\mathrm{NO}_{3}, \mathrm{NH}_{4}\right)$ as well as the carbon-nitrogen ratio. The combined manure and mineral fertilisation increased the sorption capacity, total exchangeable bases, base cation saturation and total content of $\mathrm{C}$ and $\mathrm{N}$ in comparison to organic or mineral fertilisation. As a result of lime application, an increase in these parameters was determined with the exception of total contents of carbon and nitrogen, showing no differences or a decrease. A positive effect was confirmed in five-field crop rotation, which improves physicochemical soil properties in comparison to cereal monoculture. The $\mathrm{C}: \mathrm{N}$ ratio narrows down with growing depth because more nitrogen than carbon migrates down the soil profile.
\end{abstract}

Keywords: long-term fertilisation, physico-chemical soil properties, soil profile, crop rotation, monoculture

\section{INTRODUCTION}

Soil fertility comprises many physical, chemical and biological properties. Long-term fertilisation affects the fertility more or less positively. The value of the soil environment can be also reduced through long-term intensive cultivation. According to Kuś and Siuta (1999), different systems of crop rotation have an ambiguous effect on the soil environment. However, the issue is worth attention when the number of crops in rotation is being limited and the importance of monocultures is increasing.

Long-term fertilisation causes changes in soil reaction, cation exchange capacity and base saturation (Hemalatha and Chellamathu 2013; Bednarek et al. 2012). The properties are a result of many natural and anthropogenic factors. According to the authors, soil acidity depends to a greater degree on regular liming, and to a lower degree on the form of nitrogen applied in fertilisers (Mercik and Stępień 2005).

Next to mineral fertilisation, also long-term application of manure leads to changes in the aforementioned parameters, including a considerable increase in nitrogen content in the soil environment (Wang et al. 2009, Li et al. 2010, Kołodziejczyk et al. 2017). A small part of soil nitrogen is mineral nitro- gen (1-5\%), occurring in soil as $\mathrm{NO}_{3}$ and $\mathrm{NH}_{4}$. The remaining part is organic nitrogen (Czuba et al. 1991). The content of mineral forms of nitrogen is important in ecological terms, and depends on the type of applied organic fertilisers, microbiological activity and content of water and air in the soil (Anggria et al. 2012, Antonkiewicz and Łabętowicz 2016).

The study objective was the comparison of selected physico-chemical properties in the soil profile from five year crop rotation and from rye monoculture in the conditions of long-term fertilisation experiments.

\section{MATERIAL AND METHODS}

The research was conducted based on long-term fertilisation experiments the Experimental Station of the Faculty of Agriculture and Biology of SGGW in Skierniewice. The experiment was established in 1923 on the luvisol of precipitation-gley "Stagnic Luvisols" with the content of fraction $<0.02 \mathrm{~mm}$ in horizons $\mathrm{A}_{\mathrm{p}}$ $(0-25 \mathrm{~cm})$ of $15-17 \%, \mathrm{E}_{\text {et }}(26-45 \mathrm{~cm}) 10-12 \%$, and $\mathrm{B}_{\mathrm{t}}(46-70 \mathrm{~cm}) 25 \%$ (Mercik and Stępien 2005). The analysis covered physico-chemical properties in two different crop rotations. The first one was five-year crop rotation with legume crop and manure fertilisation. The following plants are cultivated in the system: 
spring barley, lupin, winter wheat, rye, and potatoes, with manure applied every 5 years in a dose of $30 \mathrm{t} \cdot \mathrm{ha}^{-1}$. Another experimental object was rye monoculture without mineral fertilisation. Physicochemical properties of three genetic soil horizons were determined in the selected objects: $A_{p}, E_{e t}$, and $B_{t}$. The study concerned the following fertiliser combinations: $\mathrm{Ca}$ (control), CaNPK, and NPK. In limed objects, calcium oxide was applied at $1.6 \mathrm{t} \mathrm{CaO} \cdot \mathrm{ha}^{-1}$. Mineral fertilisers were applied in equal doses on all the fields at $90 \mathrm{~kg} \mathrm{~N} / \mathrm{ha}$ (ammonium nitrate), $26 \mathrm{~kg}$ $\mathrm{P} \cdot \mathrm{ha}^{-1}$ (single superphosphate) and $91 \mathrm{~kg} \mathrm{~K} \cdot \mathrm{ha}^{-1}$ (potassium chloride).

In soil samples collected in 2017 after harvest, the following parameters were determined: $\mathrm{pH}$ in $1 \mathrm{M}$ $\mathrm{KCl}$, sorption exchange capacity, total exchangeable bases and base saturation by means of the Kappen method, content of total nitrogen (by means of the Kjeldahl method) and its mineral forms: $\mathrm{NO}_{3}$ and $\mathrm{NH}_{4}$ in $0.01 \mathrm{M} \mathrm{CaCl}_{2}$ extraction as well as content of organic carbon by means of the direct method (Ostrowska et al. 1991).

The obtained results of chemical analyses of the soil were subject to statistical analysis in Statistica software with the application of two-factor analysis of variance (one factor - fertilisation, the other - crop rotation). The significance of differences was assessed by means of the Tukey method at a significance level $\alpha=0.05$.

\section{RESULTS AND DISCUSSION}

Throughout the soil profile up to $75 \mathrm{~cm}$ and in both crop rotation systems, considerably higher soil acidification occurred in objects without liming than with liming (Table 1). In rye monoculture in the nonliming combination (NPK), a strongly acidic soil reaction was determined ( $\mathrm{pH} 4.3)$. Analogically, in crop rotation, the soil reaction was acidic ( $\mathrm{pH}$ 5.0). A similar tendency was determined in research by Blecharczyk (1999), who observed that after the application of manure, $\mathrm{pH}$ was higher than after exclusive mineral fertilisation or no fertilisation. The study suggests that manure mitigated the negative effect of mineral fertilisers on soil acidification. In combinations with liming (CaNPK), no significant differences in $\mathrm{pH}$ were obtained between objects with and without manure.

The sorption exchange capacity of soils was considerably higher in the field with manure than in the field without manure (Table 1). The disproportion most probably particularly results from a high difference in the content of organic $\mathrm{C}$. It is a common belief that many soil properties are related to organic matter content (Rogasik et al. 2004, Mercik et al. 2005). In the cultivation horizon, the content of fraction $<0.02 \mathrm{~mm}$ and $<0.002 \mathrm{~mm}$ was similar in monoculture and crop rotation. For example, the content of the fractions in particular fields was respectively: monoculture -16 and $8 \%$ and crop rotation -17 and 6\% (Mercik and Stępień 2005). In all combinations and in both crop rotation systems, the sorption capacity was substantially higher in horizon $\mathrm{B}_{\mathrm{t}}$ than in cultivation horizon $\mathrm{A}_{\mathrm{p}}$. This particularly results from the higher content of fraction $<0.02 \mathrm{~mm}$ in the horizon.

The value of total exchangeable bases was lower in monoculture than in crop rotation (Table 1). The lowest value of the parameter was determined for combination NPK, i.e. one with the lowest $\mathrm{pH}$. According to Kocowicz (1999), total exchangeable bases, particularly in the humus horizons, are determined by land use and application of mineral fertilisation. Blecharczyk et al. (2002) and Mercik et al.

TABLE 1. Physico-chemical properties of soil in different long-term fertilisation and crop rotation systems

\begin{tabular}{|c|c|c|c|c|c|c|c|}
\hline \multirow[t]{2}{*}{ Soil properties } & \multirow[t]{2}{*}{ Horizon } & \multicolumn{3}{|c|}{ Monoculture } & \multicolumn{3}{|c|}{ Crop rotation } \\
\hline & & $\mathrm{Ca}$ & CaNPK & NPK & $\mathrm{Ca}$ & CaNPK & $\mathrm{NPK}$ \\
\hline $\mathrm{pH}$ in $\mathrm{KCl}$ & $\begin{array}{l}A_{p} \\
E_{e t} \\
B_{t}\end{array}$ & $\begin{array}{l}6.2 \\
6.4 \\
6.3 \\
\end{array}$ & $\begin{array}{l}6.1 \\
6.2 \\
6.1 \\
\end{array}$ & $\begin{array}{l}4.3 \\
4.3 \\
4.7\end{array}$ & $\begin{array}{l}6.1 \\
6.0 \\
5.8 \\
\end{array}$ & $\begin{array}{l}6.2 \\
6.0 \\
5.7 \\
\end{array}$ & $\begin{array}{l}5.0 \\
4.9 \\
4.9\end{array}$ \\
\hline $\begin{array}{l}\text { Sorption exchange capacity (CEC) } \\
\mathrm{cmol}(+) \cdot \mathrm{kg}^{-1}\end{array}$ & $\begin{array}{l}A_{p} \\
E_{e t} \\
B_{t}\end{array}$ & $\begin{array}{l}5.41 \\
4.62 \\
10.54 \\
\end{array}$ & $\begin{array}{l}5.62 \\
4.49 \\
10.59 \\
\end{array}$ & $\begin{array}{l}5.30 \\
4.59 \\
9.28 \\
\end{array}$ & $\begin{array}{l}7.69 \\
4.44 \\
10.60 \\
\end{array}$ & $\begin{array}{l}8.01 \\
4.80 \\
9.45\end{array}$ & $\begin{array}{l}6.98 \\
4.70 \\
8.52 \\
\end{array}$ \\
\hline $\begin{array}{l}\text { Total exchangeable bases (TEB) } \\
\mathrm{cmol}(+) \cdot \mathrm{kg}^{-1}\end{array}$ & $\begin{array}{l}A_{p} \\
E_{e t} \\
B_{t}\end{array}$ & $\begin{array}{l}4.47 \\
3.82 \\
9.7 \\
\end{array}$ & $\begin{array}{l}4.41 \\
4.03 \\
9.49 \\
\end{array}$ & $\begin{array}{l}2.93 \\
3.06 \\
7.40\end{array}$ & $\begin{array}{l}6.56 \\
3.69 \\
9.40 \\
\end{array}$ & $\begin{array}{l}6.75 \\
4.10 \\
8.7 \\
\end{array}$ & $\begin{array}{l}3.86 \\
3.04 \\
7.51 \\
\end{array}$ \\
\hline Base saturation (BS) \% & $\begin{array}{l}\mathrm{A}_{\mathrm{p}} \\
\mathrm{E}_{\mathrm{et}} \\
\mathrm{B}_{\mathrm{t}}\end{array}$ & $\begin{array}{l}83 \\
83 \\
92 \\
\end{array}$ & $\begin{array}{l}78 \\
90 \\
90 \\
\end{array}$ & $\begin{array}{l}55 \\
67 \\
80 \\
\end{array}$ & $\begin{array}{l}85 \\
83 \\
89 \\
\end{array}$ & $\begin{array}{l}84 \\
85 \\
92 \\
\end{array}$ & $\begin{array}{l}55 \\
65 \\
88 \\
\end{array}$ \\
\hline
\end{tabular}


(2000) observe that the application of mineral fertilisers leads to limiting the content of base cations in the soil and their contribution in the sorption complex. The authors add that the application of manure and lime can mitigate the state. Moreover, Blecharczyk et al. (2002) reports that the value of total exchangeable bases is not significantly affected by crop rotation. The study shows that crop rotation combined with manure fertilisation and cultivation of legume crop contributes to an increase in the sorption exchange capacity, total exchangeable bases and base saturation. According to Mazur et al. (2015), the application of organic fertilisers results in an increase in cation exchange capacity and total exchangeable bases and a decrease in hydrolytic acidity.

After 94 years of systematic fertilisation, the content of organic carbon in the humus horizon in the fields with application of manure and legume crop cultivation is considerably higher (in average by $3.3 \mathrm{~g} \cdot \mathrm{kg}^{-1}$ ) than in monoculture with no application of organic fertilisation since 1923 (Table 2). According to Mercik and Stępień (2005), content of organic carbon and total nitrogen increased even in fields without application of manure and without legume crop cultivation, although the increase was statistically significant only in the case of complete mineral fertilisation (CaNPK). A somewhat higher content of organic $\mathrm{C}$ was also determined in fields without liming than those with liming. Rogasik et al. (2004) report that intensive liming can reduce the content of organic carbon. Research by Jaskulska et al. (2014) shows an increase in the parameter in the soil after liming.
Content of total nitrogen, similarly to content of organic carbon, depended on the analysed factors. Crop rotation and legume crop cultivation had a positive effect on an increase in the content of total $\mathrm{N}$ in all soil horizons. Similar results were also obtained by Mercik et al. (1999). A somewhat broader $\mathrm{C}: \mathrm{N}$ ratio was obtained in the cultivation horizon in crop rotation than in monoculture but only in objects fertilised with mineral fertilisers and manure. No significant differences in the parameter were also obtained in research by Simon (2008). The ratio of the two elements narrows down with growing depth, and averages 10.1 in horizon $A_{p}$ and 7.3 in horizon $B_{t}$ (Table 2). This particularly results from the fact that, as shown in Table 2, more nitrogen than carbon migrates down the soil profile. In the cultivation soil horizon $\left(A_{p}\right)$, the content of total nitrogen in fields with manure and legume crop is considerably higher than in monoculture. In deeper soil profiles, differences between crop rotation systems in total $\mathrm{N}$ content in particular objects are smaller than in the cultivation horizon. As expected, higher nitrogen content in all genetic horizons was obtained in objects fertilised with nitrogen than those not fertilised with the component.

The investigated fertilisation and crop rotation systems diversified the content of mineral nitrogen $\left(\mathrm{N}-\mathrm{NH}_{4}\right.$ and $\mathrm{N}-\mathrm{NO}_{3}$ ) more than total nitrogen. Contents of $\mathrm{N}-\mathrm{NH}_{4}$ and $\mathrm{N}-\mathrm{NO}_{3}$ in the cultivation horizon are significantly higher in the field with manure and legume crop than in monoculture. Particularly low content of mineral nitrogen occurs in control fields without fertilisation. The research

TABLE 2. Total contents of $\mathrm{C}$ and $\mathrm{N}$ as well as $\mathrm{N}-\mathrm{NO}_{3}$ and $\mathrm{N}-\mathrm{NH}_{4}$ in soil after long-term variable crop rotation and fertilisation

\begin{tabular}{|c|c|c|c|c|c|c|c|c|c|}
\hline \multirow[t]{2}{*}{ Soil properties } & \multirow[t]{2}{*}{ Horizon } & \multicolumn{4}{|c|}{ Monoculture } & \multicolumn{4}{|c|}{ Crop rotation } \\
\hline & & $\mathrm{Ca}$ & CaNPK & NPK & mean & $\mathrm{Ca}$ & CaNPK & NPK & mean \\
\hline Total $\mathrm{N}$ mg $\cdot \mathrm{kg}^{-1}$ & $\begin{array}{l}A_{p} \\
E_{e t} \\
B_{t}\end{array}$ & $\begin{array}{l}329 a \\
174 a \\
184 a\end{array}$ & $\begin{array}{l}395 b \\
218 b \\
216 b\end{array}$ & $\begin{array}{l}409 b \\
241 c \\
224 b\end{array}$ & $\begin{array}{l}378 \mathrm{~A} \\
211 \mathrm{~A} \\
208 \mathrm{~A}\end{array}$ & $\begin{array}{l}634 a \\
236 a \\
210 a\end{array}$ & $\begin{array}{l}715 b \\
278 b \\
252 b\end{array}$ & $\begin{array}{l}695 b \\
281 b \\
273 b\end{array}$ & $\begin{array}{l}\text { 681B } \\
265 \mathrm{~B} \\
245 \mathrm{~B}\end{array}$ \\
\hline $\mathrm{N}-\mathrm{NO}_{3} \mathrm{mg} \cdot \mathrm{kg}^{-1}$ & $\begin{array}{l}\mathrm{A}_{\mathrm{p}} \\
\mathrm{E}_{\mathrm{et}} \\
\mathrm{B}_{\mathrm{t}}\end{array}$ & $\begin{array}{l}19.7 \mathrm{a} \\
17.9 \mathrm{a} \\
18.0 \mathrm{a} \\
\end{array}$ & $\begin{array}{l}42.8 \mathrm{c} \\
41.5 \mathrm{~b} \\
27.4 \mathrm{~b}\end{array}$ & $\begin{array}{l}35.1 \mathrm{~b} \\
38.1 \mathrm{~b} \\
24.0 \mathrm{~b} \\
\end{array}$ & $\begin{array}{l}32.5 \mathrm{~A} \\
32.5 \mathrm{~A} \\
23.1 \mathrm{~A}\end{array}$ & $\begin{array}{l}46.6 \mathrm{a} \\
28.2 \mathrm{a} \\
24.4 \mathrm{a} \\
\end{array}$ & $\begin{array}{l}54.7 \mathrm{~b} \\
32.4 \mathrm{a} \\
28.9 \mathrm{~b} \\
\end{array}$ & $\begin{array}{l}58.6 \mathrm{~b} \\
30.8 \mathrm{a} \\
27.1 \mathrm{~b}\end{array}$ & $\begin{array}{l}53.3 \mathrm{~B} \\
30.5 \mathrm{~A} \\
26.8 \mathrm{~A} \\
\end{array}$ \\
\hline $\mathrm{N}-\mathrm{NH}_{4} \mathrm{mg} \cdot \mathrm{kg}^{-1}$ & $\begin{array}{l}A_{p} \\
E_{e t} \\
B_{t}\end{array}$ & $\begin{array}{l}8.22 \mathrm{a} \\
6.91 \mathrm{a} \\
6.32 \mathrm{~b} \\
\end{array}$ & $\begin{array}{l}22.3 \mathrm{~b} \\
9.56 \mathrm{~b} \\
4.54 \mathrm{a} \\
\end{array}$ & $\begin{array}{l}30.5 \mathrm{c} \\
14.9 \mathrm{c} \\
8.34 \mathrm{c} \\
\end{array}$ & $\begin{array}{l}20.3 \mathrm{~A} \\
12.2 \mathrm{~A} \\
6.4 \mathrm{~A} \\
\end{array}$ & $\begin{array}{l}56.1 \mathrm{a} \\
46.0 \mathrm{a} \\
31.5 \mathrm{a} \\
\end{array}$ & $\begin{array}{l}57.4 \mathrm{a} \\
64.8 \mathrm{~b} \\
37.9 \mathrm{~b} \\
\end{array}$ & $\begin{array}{l}55.6 \mathrm{a} \\
67.6 \mathrm{~b} \\
37.6 \mathrm{~b} \\
\end{array}$ & $\begin{array}{l}56.4 \mathrm{~B} \\
59.5 \mathrm{~B} \\
35.7 \mathrm{~B} \\
\end{array}$ \\
\hline Organic $\mathrm{C} \mathrm{g} \cdot \mathrm{kg}^{-1}$ & $\begin{array}{l}A_{p} \\
E_{e t} \\
B_{t}\end{array}$ & $\begin{array}{l}3.58 \mathrm{a} \\
1.58 \mathrm{a} \\
1.37 \mathrm{a}\end{array}$ & $\begin{array}{l}3.66 \mathrm{a} \\
2.05 \mathrm{~b} \\
1.57 \mathrm{~b}\end{array}$ & $\begin{array}{l}3.78 \mathrm{a} \\
2.11 \mathrm{~b} \\
1.63 \mathrm{~b}\end{array}$ & $\begin{array}{l}3.7 \mathrm{~A} \\
1.9 \mathrm{~A} \\
1.5 \mathrm{~A}\end{array}$ & $\begin{array}{l}6.65 \mathrm{a} \\
2.27 \mathrm{a} \\
1.67 \mathrm{a}\end{array}$ & $\begin{array}{l}7.18 \mathrm{~b} \\
2.60 \mathrm{~b} \\
1.78 \mathrm{a}\end{array}$ & $\begin{array}{l}7.20 \mathrm{~b} \\
2.67 \mathrm{~b} \\
1.80 \mathrm{a}\end{array}$ & $\begin{array}{l}7.0 \mathrm{~B} \\
2.5 \mathrm{~B} \\
1.8 \mathrm{~A}\end{array}$ \\
\hline $\mathrm{C:N}$ & $\begin{array}{l}A_{p} \\
E_{e t} \\
B_{t}\end{array}$ & $\begin{array}{l}10.9 \\
9.2 \\
7.6\end{array}$ & $\begin{array}{l}9.1 \\
9.2 \\
7.4\end{array}$ & $\begin{array}{l}9.3 \\
8.7 \\
7.1\end{array}$ & $\begin{array}{l}9.8 \\
9.0 \\
7.4\end{array}$ & $\begin{array}{r}11.0 \\
9.7 \\
7.6\end{array}$ & $\begin{array}{l}9.8 \\
8.6 \\
7.1\end{array}$ & $\begin{array}{r}10.5 \\
10.3 \\
7.0\end{array}$ & $\begin{array}{r}10.4 \\
9.5 \\
7.2 \\
\end{array}$ \\
\hline
\end{tabular}

Values for fertilisation in particular soil horizons marked with a lowercase letter are not significantly different for $\alpha=0.05$, and the comparison for mean values in crop rotation is marked with a capital letter. 
evidenced greater migration of nitrate nitrogen in comparison to the ammonium form, as confirmed by research by Sosulski and Mercik (2011). Greater migration of $\mathrm{NO}_{3}$ was recorded in monoculture than in crop rotation, with manure fertilisation and lupin cultivation. Migration of the ammonium form was significantly higher in crop rotation than in monoculture. This results from considerably higher content of the organic form of nitrogen in crop rotation, where the first stage of mineralisation is the ammonium form. Differences between the combinations with nitrogen fertilisation and control group were more than twice as high as in rye monoculture than in crop rotation. In five-year crop rotation, the difference in the content of mineral forms of nitrogen between control group and combinations NPK and CaNPK was substantially lower, because high amounts of organic nitrogen from long-term application of manure and from harvest residues were subject to systematic mineralisation, enriching the soil with this fraction of nitrogen. A somewhat greater migration of the ammonium form, and smaller of the nitrate form was obtained in acidic than in limed soil. This probably results from limiting the intensification of nitrification in acidic soil.

\section{CONCLUSIONS}

1. Long-term manure application mitigates the negative effect of mineral fertilisers on soil acidification. Nonetheless, lime application is the primary factor preventing soil acidification.

2. Mineral fertilisation combined with organic fertilisation and liming increases cation exchange capacity, total exchangeable bases and base saturation in comparison to exclusive organic or mineral fertilisation.

3. After 94 years of systematic manure fertilisation in the humus horizon, the content of organic carbon in fields with application of manure and legume crop is almost twice as high as in rye monoculture without application of organic fertilisation since 1923.

4. The carbon to nitrogen ratio narrows down with growing depth, because more nitrogen than carbon migrates down the soil profile.

5. In five-year crop rotation, migration of nitrates is lower and migration of the ammonium form of nitrogen is higher than in rye monoculture.

6. Soil in five-year crop rotation with legume crop and manure fertilisation is characterised by considerably higher fertility than soil in cereal monoculture without manure fertilisation for several decades.

\section{REFERENCES}

Anggria L., Kasno A., Rochayati S., 2012. Effect of organic matter on nitrogen mineralization in flooded and dry soil ARPN. Journal of Agricultural \& Biological Science 7(8): 586.

Antonkiewicz J., Łabętowicz J., 2016. Chemical innovation in plant nutrition in a historical continuum from ancient Greece and Rome until modern times. Chemistry Didactics Ecology Metrology 21(1-2): 29-43.

Bednarek W., Dresler S., Tkaczyk P. and Hanaka A., 2012. Influence of liquid manure and NPK on selected sorption properties of soil. Journal of Elementology 17 (4): 547-557.

Blecharczyk A., 1999. Forty-years o fertilizating experiment in brody with crops grown continously and in crop rotation. Zeszyty Postępów Nauk Rolniczych 465: 261-272.

Blecharczyk A., Małecka I., Piechota T., 2002. Wpływ wieloletniego nawożenia oraz następstwa roślin na właściwości gleby i skład chemiczny jęczmienia jarego. Zeszyty Postępów Nauk Rolniczych 482: 59-64.

Czuba R., Gorlach E., Kalembasa S., Łoginow W., Mazur T., 1991. Azot w glebach uprawnych. PWN, Warszawa, pp. 239

Hemalatha S., Chellamuthu S., 2013. Impacts of long term fertilization on soil nutritional quality under finger millet maize cropping sequences. Journal of Environmental Research And Development 7(4a): 1571.

Jaskulska I., Jaskulski D., Kobierski M., 2014. Effect of liming on the change of some agrochemical soil properties in a longterm fertilization experiment. Plant Soil and Environment 60(4): 146-150.

Kocowicz A., 1999. Wpływ sposobu użytkowania na właściwości sorpcyjne gleb. Zeszyty Problemowe Postępów Nauk Rolniczych 467: 95-101.

Kołodziejczyk M., Antonkiewicz J., Kulig B., 2017. Effect of living mulches and conventional methods of weed control on weed occurrence and nutrient uptake in potato. International Journal of Plant Production 11(2): 275-284.

Kuś J., Siuta A., 1999. Wpływ zmianowań zbożowych na wybrane wskaźniki żyzności gleby. Zeszyty Problemowe Postępów Nauk Rolniczych 467: 89-94.

Li Z.P., Liu M., Wu X.C., Han F.X., Zhang T.L., 2010. Effects of long-term chemical fertilization and organic amendments on dynamics of soil organic $\mathrm{C}$ and total $\mathrm{N}$ in paddy soil derived from barren land in subtropical. China. Soil Till Research 106: 268.

Mazur Z., Sienkiewicz S., Mazur T., 2015. The influence of multi-year organic and mineral fertilisation of the physicochemical properties of lessive soil. Polish Journal of Soil Science 48(1): 79-89.

Mercik S., Stępień W., 2005. The most important soil properties and yields of plants in 80 years of statistic fertilizing experiments in Skierniewice. Fragmenta Agronomica 1(85): 189-201.

Mercik S., Stępień W., Lenart S., 2000. Żyzność gleb w trzech systemach nawożenia: mineralnym, organicznym i organiczno-mineralnym - w doświadczeniach wieloletnich. Cz. 1. Właściwości fizyczne i fizykochemiczne gleb. Folia Universities Agricultural Stettinius 211, Agricult. 84: 311-316.

Mercik S., Stępień W., Sosulski T., 1999. Bilans azotu nawozowego w wieloletnich doświadczeniach polowych w Skierniewicach. Zeszyty Problemowe Postępów Nauk Rolniczych 465: 71-80. 
Mercik S., Stępień W., 2005. The most important soil properties and yields of plants in 80 yeras of statistic ferttilizing experiments in Skierniewice, Fragmenta Agronomica 1(85) 189200.

Mercik S., Stępień M., Stępień W., Sosulski T., 2005. Dynamics of organic carbon content in soil depending on long-term fertilization and crop rotation. Roczniki Gleboznawcze - Soil Science Annual 56(3/4): 53-59.

Ostrowska A., Gawliński S., Szczubiałka Z., 1991. Methods of analysis and assessment of soil and plant properties. A Catalgoue. Publisher: Institute of Environmental Protection - National Research Institute Warsaw: pp. 334.

Rogasik J., Schroetter S., Funder U., Schnug E., Kurtinecz P., 2004. Long-term fertilizer experiments as a data base for calculating the carbon sink potential of arable soils. Archives of Agronomy and Soil Science 50: 11-19.
Simon T., 2008. The influence of long-term organic and mineral fertilization on soil organic matter. Soil and Water Research. 3(2): 41-51.

Sosulski T., Mercik S., 2011. Dynamics of mineral nitrogen movement in the soil profile in long-term experiments. Ecological Chemistry and Engineering 18(4): 611-617.

Wang J., Lin X., Yin R., Chu H., Chen M., Dai J., Qin S., 2009. Changes in soil humic acid, microbial biomass carbon and invertase activity in response to fertilization regimes in a longterm field experiment. Journal of Plant Nutrition and Fertilizer Science 15(2): 352.

Received: February 14, 2019

Accepted: April 12, 2019

Associated editor: B. Rutkowska

\section{Wpływ wieloletniego nawożenia organicznego i mineralnego na wybrane właściwości fizykochemiczne gleby w monokulturze żyta i zmianowaniu pięciopolowym}

Streszczenie: Wieloletnie doświadczenia nawozowe zlokalizowane w Stacji Doświadczalnej SGGW w Skierniewicach prowadzone są nieprzerwanie od 1923 roku. Badania te miały na celu określenie wybranych właściwości fizykochemicznych gleby po wieloletnim nawożeniu (Ca, CaNPK, NPK) oraz w danym systemie zmianowania (monokultura żyta bez nawożenia obornikiem i zmianowanie pięciopolowe $\mathrm{z}$ rośliną bobowatą oraz z nawożeniem obornikiem). W trzech poziomach genetycznych gleby $\left(\mathrm{A}_{\mathrm{p}}, \mathrm{E}_{\mathrm{et}}\right.$, $\mathrm{B}_{\mathrm{t}}$ ) zbadano: $\mathrm{pH}$ w KCl, pojemność wymiany kationów, sumę kationów zasadowych oraz stopień wysycenia kompleksu sorpcyjnego kationami zasadowymi. Oznaczono również ogólną zawartość węgla i azotu oraz jego form mineralnych $-\mathrm{NO}_{3}$ i $\mathrm{NH}_{4}$, a także określono stosunek $\mathrm{C}$ do $\mathrm{N}$. Na podstawie uzyskanych wyników wykazano, że nawożenie mineralno-organiczne w największym stopniu powoduje zwiększenie kationowej pojemności wymiennej gleby, sumy kationów zasadowych, stopnia wysycenia kompleksu sorpcyjnego kationami zasadowymi oraz ogólnych zawartości $\mathrm{C}$ organicznego i $\mathrm{N}$ w porównaniu do wyłącznego nawożenia organicznego lub mineralnego. Wapnowanie również wpłynęło na zwiększenie wartości tych parametrów, z wyjątkiem zawartości węgla i azotu, dla których te różnice nie były istotne statystycznie. Przykładem tego jest monokultura żyta, w której odnotowano nawet obniżenie ogólnych zawartości C i N w warstwie ornej pod wpływem zastosowanych nawozów wapniowych. Zmianowanie polepszało właściwości fizykochemiczne gleby w porównaniu do monokultury zbożowej, dzięki czemu poprawiało jej żyzność. Stosunek węgla do azotu zawężał się w miarę głębokości, ponieważ w głąb profilu glebowego przemieszczało się więcej azotu niż węgla.

Stowa kluczowe: wieloletnie nawożenie, właściwości fizykochemiczne gleby, profil glebowy, zmianowanie, monokultura 